\title{
Once again on Discosphaerina
}

\author{
LENNART HOLM, KERSTIN HOLM and MARGARET E. BARR
}

HOLM, L., HOLM, K. \& BARR, M.E. 1999: Once again on Discosphaerina. - Karstenia 39: 59-63. Helsinki. ISSN 0453-3402

\begin{abstract}
Discosphaerina Höhn. is reinstated as a valid generic name, typified by $D$. discophora Höhn., for some small, amerosporous, unitunicate Ascomycetes that fit best within the family Hyponectriaceae. The new combinations D. niesslii (Kunze ex Rehm) L. Holm, K. Holm \& M.E. Barr, and D. lonicerae (Dearn. \& Barthol.) L. Holm, K. Holm \& M.E. Barr are made, and the new species D. sorbi L. Holm, K. Holm \& M.E. Barr is described. Guignardia Viala \& Ravaz, nom. cons., is accepted for similar small, amerosporous but bitunicate Ascomycetes in the Dothideaceae.
\end{abstract}

Key words: Ascomycetes, Hyponectriaceae, Dothideaceae, taxonomy, morphology

Lennart Holm \& Kerstin Holm, Botanical Museum, Uppsala University, Norbyvägen 16, SE-752 36 Uppsala, Sweden

Margaret E. Barr, 9475 Inverness Road, Sidney, British Columbia, Canada V8L 5G8

\section{Introduction}

Within the past few years, we have been puzzled by several amerosporous ascomycetes that lack a defined ostiole and periphyses, and open irregularly between cells in the upper region of ascomata. The small ascomata are sphaeroid, often collabent on drying, and are visible as dark sunken dots in the affected tissues. The thin-walled apical cells are usually encircled by one or two rows of dark-walled pseudoparenchymatous cells that continue as the lateral and basal peridium. A shallow clypeus of textura epidermoidea may extend from the upper surface. The hymenium lacks paraphyses, or occasionally a few are seen compressed between asci; the asci arise from a wide basal subhymenial layer, and have a somewhat thickened wall that lacks an ocular chamber or obvious apical ring. The asci have not been observed to open in a fissitunicate fashion. A critical observation made recently is that following alkaline pretreatment (Kohn \& Korf 1975) a low or well developed, amyloid apical ring is seen to be present.
Arwidssonia B. Erikss. is similar by habit in leaves and by the collabent lenticular ascomata that open by three to five lobes. Arwidssonia empetri (Rehm) B. Erikss. is a phragmosporous taxon. The hymenium does exhibit paraphyses, and the ascus apices are amyloid after pretreatment. Eriksson (1974) did not indicate familial position of the genus. Barr (1976) assigned it to the Physosporellaceae, i.e. Hyponectriaceae, and it has remained there ever since (e.g., Hawksworth et al. 1995, Eriksson \& Hawksworth 1998). The taxa in question also share many features with Hyponectria Sacc., where periphysate ostioles are formed. In that genus, H. buxi (Alb. \& Schwein. : Fr.) Sacc. has nonamyloid ascus apices, although most other species presently included (Barr 1977) have amyloid apices. The amyloid reaction appears to be variable within genera or among species of a genus and does not constitute a good family characteristic. 


\section{The taxonomic problem}

To determine a possible genus, we investigated the past disposition of some of the species involved. Discosphaerina Höhn. was assigned to synonymy under Guignardia Viala \& Ravaz by Arx and Müller (1954). Several of the species that they illustrated have strongly sphaeroid, nonostiolate ascomata; Arx and Müller indicated that the asci were bitunicate. Discosphaerina is typified by $D$. discophora Höhn., on leaves of Solidago. Höhnel (1917) observed that it differed from Guignardia by the plane, nonostiolate apical region of shallow ascomata and absence of paraphyses. He described thin-walled asci. Petrak (1920) described Guignardia steppani on the same host plant, and in 1921 reduced it to synonymy under $D$. discophora. This is one of the group of taxa that we have examined recently.

Petrak (1924) emended the description of Discosphaerina to include several other species with additional stromatic tissues connecting ascomata. He assigned Laestadia niesslii Kunze to Physalospora Niessl because of the occasional presence of paraphyses among asci. This taxon is another one that provided the stimulus for the present investigation. It is the sole species of Laestadiella Höhn., the genus name itself a nomen nudum. The species forms sphaeroid, nonostiolate ascomata with abundant hyphae connecting ascomata; the asci are thin walled, are not bitunicate, and have an amyloid apical ring after KOH- pretreatment. Klebahn (1918) provided a detailed description and illustrations of the fungus as Guignardia. He emphasized the flattened upper region of the ascoma that gives a turbinate shape to the structure in section, and that opens rather widely at maturity. He also noted that asci develop from a wide basal layer, rather than in a fascicle from a restricted subhymenium, have a scarcely thickened wall, and lack paraphyses. His cultures yielded conidia in age from short contorted hyphae, interpreted by Sivanesan (1984) as belonging to Aureobasidium. Klebahn's attempted infection of living plants failed.

\section{Unitunicate Discosphaerina}

We believe the evidence is convincing that Discosphaerina is indeed an unitunicate taxon, and that the genus should be utilized for this particular group of species. Their disposition in the Hy- ponectriaceae points to a close relationship with Arwidssonia on the one hand, and Hyponectria on the other. We propose the following synonymy and include the names of a few other species, as well as an undescribed species, that belong in the genus.

Discosphaerina Höhn., Sitzungsber. Kaiserl. Akad. Wiss., Nat.-Math. K1. 126: 353. 1917. Type species: D. discophora Höhn., Fig. 6. syn. Guignardia steppani Petr. On leaves and stems of Solidago.

= Laestadiella Höhn., Ann. Mycol. 16: 50. 1918, nom. nud. Sole species: L. niesslii (Kunze ex Rehm) Höhn. = Discosphaerina niesslii (Kunze ex Rehm) L. Holm, K. Holm \& M.E. Barr, comb. nov. Basionym: Laestadia niesslii Kunze, Fungi sel. exs. 241, nom. nud.; ex Rehm, Hedwigia 20: 53. 1881. On leaves of Populus and Salix spp.

Additional species:

Discosphaerina epilobii (Wallr.) Petr. On stems of Epilobium spp.

Discosphaerina lonicerae (Dearn. \& Barthol.) L. Holm, K. Holm \& M.E. Barr, comb. nov. Basionym: Guignardia lonicerae Dearn. \& Barthol. Mycologia 18: 245. 1926 (Barr 1977 under Hyponectria). On leaves of Loni-cera spp.

Discosphaerina punctoidea (Cooke) Petr. On leaves of Quercus spp.

Discosphaerina sorbi, L. Holm, K. Holm \& M.E. Barr, sp. nov. - Figs. 1-5.

Species nova margine distincto peritheciorum imprimis insignis.

Holotype: Sweden. Jämtland. Åre parish: Enafors, c. $500 \mathrm{~m} \mathrm{SE}$ of the railway station, in mixed forest along the road to Handöl, 12.6.1998 (matured at "Jerusalem" until 15.7.1998) K.\& L. Holm 6170 (UPS).

Ascomata epiphyllous, subcuticular, gregarious, often two or three confluent, generally 0.1$0.2 \mathrm{~mm}$ diam., including a distinct margin, up to 40 $\mu \mathrm{m}$ broad, first very broadly conical, later collapsing. Peridium mostly $10-15 \mu \mathrm{m}$ broad (laterally more), of 2-3 layers of cells (laterally more); the upper part composed of somewhat radially arranged cells up to $15 \mu \mathrm{m}$ long, basally the cells smaller and more angular; laterally the peridium is made up of larger cells, up to $20 \mu \mathrm{m}$ and passing into a clypeal margin of textura epidermoidea 

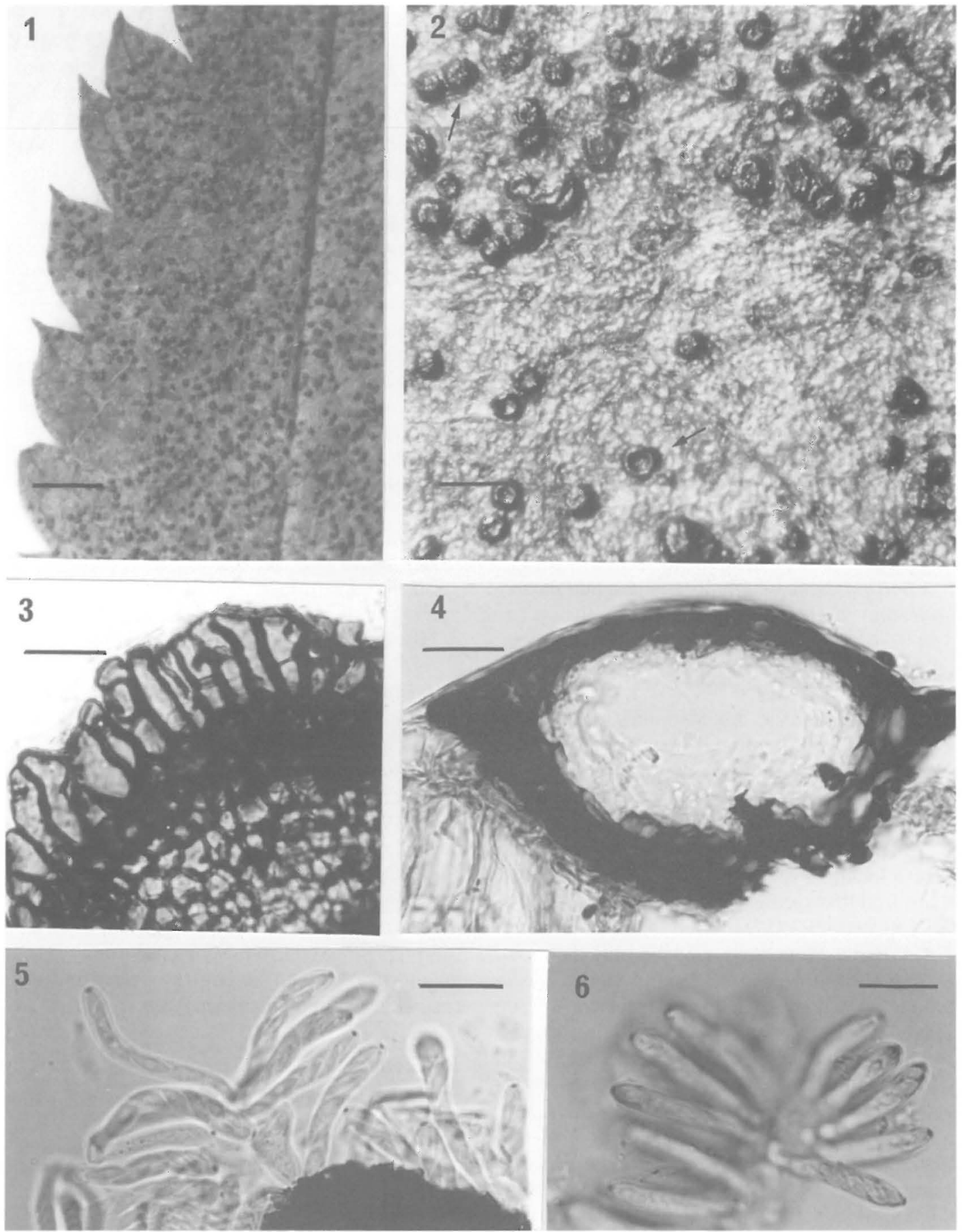

Figs. 1-5: Discosphaerina sorbi. 1. Ascomata on leaf of Sorbus aucuparia (Holm \& Holm 6170). Bar = $1 \mathrm{~mm} .2$. Ditto, clypeus visible at arrows. Bar $=0.2 \mathrm{~mm}$. 3. Part of crushed ascoma, clypeus seen from above $(6170)$. Bar $=20$ $\mu \mathrm{m}$. 4. Ascoma in section, with lateral clypeus (4096). Bar $=20 \mu \mathrm{m}$. 5. Asci with apical annulus $\mathrm{J}_{+}$after $\mathrm{KOH}-$ pretreatment $(4087 a)$. Bar $=20 \mu \mathrm{m}$. Fig. 6: D. discophora. Asci with apical annulus J+ after KOH-pretreatment (Petr., Fl. Bohem. Mor. exs. II: 1 no 1232 sub nom. Guignardia steppani). Bar $=20 \mu \mathrm{m}$. 
composed of one layer of elongated, often lobed cells, up to $40 \mu \mathrm{m}$. Paraphyses none. Asci generally 55-60 $\times 5-6 \mu \mathrm{m}$, cylindric-clavate, 8 -spored, with a small apical annulus, J+ after $\mathrm{KOH}-$ pretreatment. Ascospores nonseptate, hyaline, about ellipsoid, somewhat unequally flattened, $9-13 \times 3.5-5 \mu \mathrm{m}$. In last year's fallen leaves of Sorbus aucuparia L.

Additional material seen: Härjedalen. Hede parish: Nysäter, c. $180 \mathrm{~m} \mathrm{~S}$ of the inn "Orren," regio subalp., c. $870 \mathrm{~m}, 7.6 .1998 \mathrm{~K}$. \& L. Holm 6148 (UPS). Jämtland. Åre parish: Storlien, swampy ground of Fjällien, regio subalp., 26.5.1984 I. Sperber (DAOM, UPS). Oviken parish: Persåsen, c. 500 m NNE of the hotel "Blå lampan" 13.6.1998 K. \& L. Holm 6171 (UPS). Torne Lappmark. Jukkasjärvi parish: Mt Nuolja, near the lift station, regio subalp., 4.7.1986 K. \& $L$. Holm 4087a, 4096 (UPS).

It is noteworthy that this conspicuous fungus so far has been found only in the subalpine and adjacent regions of north Sweden. The host, Sorbus aucuparia, is widely distributed and mostly common.

\section{Similar bitunicate taxa}

The small, bitunicate, amerosporous taxa now require some consideration. When Arx and Müller (1954) included several of the taxa noted above under Guignardia Viala \& Ravaz, they assigned to the genus small taxa (most less than $200 \mu \mathrm{m}$ diam), without distinct apical papilla and with sparse locule tissues (or paraphyses) to separate them from the species of Botryosphaeria Ces. \& DeNot. Petrak (1957) argued that Botryosphaeria comprised four sections, including the group of Guignardia bidwellii (Ellis) Viala \& Ravaz which contained such small taxa, mostly on leaves. He recognized Discosphaerina as distinctive on the bases of small sizes, lack of an ostiole and usually of paraphyses. Barr (1972) accepted Botryosphaeria in Petrak's wide sense, as a member of the Dothioraceae, and considered Discosphaerina to belong in the Dothideaceae. Later (Barr 1987) she assigned both Botryosphaeria and Guignardia (as Discochora) to the Botryosphaeriaceae of the Pleosporales, but retained Discosphaerina in the Dothideaceae of the Dothideales. The argument over locule tissues in Guignardia has been a problem for determining the familial status of the genus. Studies of numerous collections within the genus showed no pseudoparaphyses present at maturity, but only interthecial cells that become compressed between and above the developing asci. Aa (1973) had a similar view of the locule in Guignardia. Janex-Favre et al. (1996) argued that such structures did develop, coexisting with carpocentral cells, and that Guignardia should be assigned to the Botryosphaeriaceae. Recent classifications, such as Eriksson (1992), Hawksworth et al. (1995), Eriksson and Hawksworth (1998), have Guignardia in the Mycosphaerellaceae, Botryosphaeria in the Botryosphaeriaceae, i.e., with interthecial cells in Guignardia, pseudoparaphyses in Botryosphaeria. The Dothideaceae, including Mycosphaerellaceae, for taxa having uni- or multiloculate ascomata, would seem to be suitable to house Guignardia.

Guignardia Viala \& Ravaz, nom. cons., Bull. Soc. Mycol. France 8: 63. 1892. Type species: G. bidwellii (Ellis) Viala \& Ravaz.

Discochora Höhn., Ber. Deutsche Bot. Gesell. 36: 315. 1918. Type species: D. ilicis (Schleich. ex Ellis) Höhn. = Guignardia philoprina (Berk. \& Curtis) Aa, Stud. Mycol. Baarn 5: 44. 1973.

Leptophacidium Höhn., Sitzungsber. Kaiserl. Akad. Wiss., Nat.-Math. Kl. 127: 4. 1918. Type species: L. umbelliferarum (Rabenh.) Höhn. = Guignardia foeniculata (Mont.) Arx \& E. Müll., Beitr. Kryptogamenfl. Schweiz, 11(1): 48. 1954.

Anamorphs in a number of species belong in Phyllosticta, with holoblastic conidiogenous cells, and phialidic spermatia in Leptodothiorella (Aa 1973); several species form Kabatia anamorphs (Reusser 1964, Sivanesan 1984). These anamorphs fit well among the varied ones already known in the Dothideaceae.

\section{References}

Aa, H.A. van der. 1973: Studies in Phyllosticta I. - Stud. Mycol. 5: 1-110.

Arx, J.A. von \& Müller, E. 1954: Die Gattungen der amerosporen Pyrenomyceten. - Beitr. Kryptogamenfl. Schweiz 11(1): 1-434.

Barr, M.E. 1972: Preliminary studies on the Dothideales in temperate North America. - Contr. Univ. Michigan Herb. 9: 523-638.

Barr, M.E. 1976: Buergenerula and the Physosporellaceae. - Mycologia 68: 611-621.

Barr, M.E. 1977: Magnaporthe, Telimenella, and Hyponectria (Physosporellaceae). - Mycologia 69: 952-966. 
Barr, M.E. 1987: Prodromus to Class Loculoascomycetes. - Publ. by the author, Amherst, MA. 168 pp.

Eriksson, B. 1974: On Ascomycetes on Diapensiales and Ericales in Fennoscandia 2. Pyrenomycetes. Svensk Bot. Tidskr. 68: 192-234.

Eriksson, O.E. 1992: The non-lichenized pyrenomycetes of Sweden. - SBT-förlaget, Lund, Sweden. $208 \mathrm{p}$.

Eriksson, O.E. \& Hawksworth, D.L. 1998: Outline of the ascomycetes -1998. - Syst. Ascomyc. 16: 83296.

Hawksworth, D.L., Kirk, P.M., Sutton, B.C. \& Pegler, D.N. 1995: Ainsworth \& Bisby's Dictionary of the fungi, 8th ed. - CAB International, Wallingford, England. $616 \mathrm{pp}$.

Höhnel, F. von 1917: Fragmente zur Mykologie n. 1031. Discosphaerina n. G. v. H. - Sitzungsber. Kaiserl. Akad. Wiss. Math.-Naturwiss. Kl. Abt. 1, 126: 353-354.

Janex-Favre, M.C., Parguey-Leduc, A. \& Jailloux, F. 1996: The ontogeny of perithecia in Guignardia bidwellii. - Mycol. Res. 100: 875-880.
Klebahn, H. 1918: Haupt- und Nebenfruchtformen der Ascomyzeten. - Borntraeger, Leipzig. 395 pp.

Kohn, L.M. \& Korf, R.P. 1975: Variation in ascomycete iodine reactions; $\mathrm{KOH}$ pretreatment explored. - Mycotaxon 3: 165-172.

Petrak, F. 1920: Der mykologische Nachlass Josef Jahn's, ein Beitrag zur Pilzflora des Egerlandes. Ann. Mycol. 18: 105-135.

Petrak, F. 1921: Mykologische Notizen. 100. Über Guignardia Steppani Petrak. - Ann. Mycol. 19: 110112.

Petrak, F. 1924: Mykologische Notizen. 319. Über Laestadia scabiosae Lamb. et Faut. - Ann. Mycol. 22: 35-36.

Petrak, F. 1957: Über die Gattungen Guignardia Viala et Ravaz und Discosphaerina v. Höhn. - Sydowia 11: 435-445.

Reusser, F.A. 1964: Über einige Arten der Gattung Guignardia Viala et Ravaz. - Phytopathol. Z. 51: 205240 .

Sivanesan, A. 1984: The bitunicate Ascomycetes and their anamorphs. - J. Cramer, Vaduz. 701 pp.

Received on 9 August 1999. 